\section{Towards a Model of Rhetorical Criticism of Metonymy in Chinese Media Texts}

\author{
$\mathrm{Ke} \mathrm{Li}$ \\ School of Translation Studies, Shandong University, Weihai \\ 180 Wenhua St. Weihai, Shandong, China \\ Tel: 86-18363136069Ｅ-mail: keylee_0925@163.com
}

Shukang Li (Corresponding author)

School of Translation Studies, Shandong University, Weihai

180 Wenhua St. Weihai, Shandong, China

Tel: 86-18363136369Ｅ-mail: lishukang@sdu.edu.cn

Received: August 5, 2015 Accepted: August 22, 2015 Published: August 23, 2015

doi:10.5296/10.5296/elr.v1i2.8120ＵRL: http://dx.doi.org/10.5296/elr.v1i2.8120

\begin{abstract}
Rhetorical criticism is a type of criticism with rhetorical phenomena as its object. In the context of western rhetoric, rhetorical criticism is usually viewed as a method to describe, explain and evaluate certain rhetorical phenomena or act. Metonymy, as a kind of rhetorical device in traditional rhetoric and a cognitive tool in cognitive linguistics, can be regarded as an object for criticism. Accordingly, an analysis of metonymy from the perspective of rhetorical criticism can disclose text builders' rhetorical motive behind the linguistic use of metonymy. Moreover, it can reveal the ideological meaning of the text (a weak version of ideology) by analyzing and evaluating the terministic screen constructed by the metonymy, to achieve the purpose of rhetorical persuasion and build an "identification" between the addresser and addressee.
\end{abstract}

Keywords: Metonymy, Rhetorical criticism, Terministic screen, Chinese media text, Rhetorical motive 


\section{Introduction}

Since the publication of Metaphors We Live by (1980), metonymy research has gained more attention from scholars at home and abroad than before. Studies in this field can be subdivided into three parts: 1) the basic mechanism of metonymy, including such parameters as ideational cognitive model (ICM), contiguity, script, schema, cognitive domain, conceptualization, logic, etc.; 2) the analyses of words, suntax, semantic meaning, pragmatic meaning, text from the perspective of metonymy; 3) the interpretation of metonymy from multi-perspectives, including critical discourse analysis (CDA) (Hart, 2011), relevance theory (Jiang, 2011), philosophy (K. Li \& S. K. Li, 2012), corpus linguistics (Stefanowwitsch, 2006), etc. In this study, we are to introduce a new perspective to analyze metonymy, namely, rhetorical criticism, together with such subsidiary theories as terministic screen, rhetorical situation, rhetorical motive, ideology, identification.

The study is carried out on the basis of the following three points: 1) metonymy is prevailing in Chinese as well as in English; 2) metonymy, as a rhetorical phenomenon, can be viewed as an analytical object for rhetorical criticism; 3) the three steps of rhetorical criticism: description, explanation and evaluation will be employed to the analysis of metonymy.

\section{Theoretical Framework}

\subsection{Theoretical Foundation: Rhetorical Criticism}

Many scholars define rhetorical criticism in their own way. Foss (2004), Hart \& Daughton (2005), Kuypers \& King (2005), Althouse, et al. (2009), Burgchardt (2010), Ott \& Dickinson (2012) all made some contributions to the concept of rhetorical criticism. Foss $(2004$, p. 6) points out that rhetorical criticism is a qualitative research method that is designed for the systematic investigation and explanation of symbolic acts and artifacts for the purpose of understanding rhetorical processes. Hart \& Daughton (2005) claims that rhetorical criticism is an act to recognize the complexity of rhetorical phenomena and to interpret them in a comprehensive and effective manner. All the other scholars hold the similar opinion that the object of rhetorical criticism is rhetorical phenomena, or rhetorical act, or symbolic act and that the method of rhetorical criticism is a systematic analysis and evaluation.

Rhetorical criticism now develops towards diversified directions, and it is proved that the current methods amount to 60 kinds, therefore, there must be various kinds of procedures of rhetorical criticism. Campbell \& Burkholder (1997) demonstrates four main steps to do criticism, namely, description, analysis, interpretation and evaluation. To be concrete, description means describing rhetorical acts and text, analysis means analyzing the historical and cultural background of rhetorical acts and texts to disclose the rhetor's motive, interpretation means choosing a critical angle, and evaluation means evaluating rhetorical acts and texts as objectively as possible. These four steps can investigate the process of rhetorical criticism, there are some redundancy among them, however. For instance, analysis which is a broad term and interpretation which also shares the meaning with explanation can be integrated into explanation. In a word, the procedures of rhetorical criticism can be listed as following: description, explanation and evaluation. The first step is to describe the object 
of criticism, the second is to explain the social and cultural background of the rhetorical act and thus to disclose the rhetorical motive and ideology behind it, and the third is to evaluate the result of criticism on the basis of some relevant standards.

\subsection{The Development of Criticism}

Criticism appears in many different fields, such as literature criticism, translation criticism, etc. "The word criticism stems from Greek Krisis, which means judgment." (Black, 1978, p. 29) criticism has at least two meanings, one is "fault-finding"; the other is "making judgment", usually for literary art. The connotation of criticism in meotnymy criticism belongs to the second meaning.

Different schools make different definitions of criticism. Rhetorical criticism researchers have their special concern about it. Andrews (1983, p. 45) gives criticism such a definition as "a systematic process of illuminating and evaluating products of human activity". Hart \& Daughton (2004, p. 30) distinguishes criticism as "an act of identifying and interpreting some phenomenon comprehensively and effectively." Crowley \& Stancliff (2011, p. 10) moves further to state that "critical is the practice of inquiry and analysis." Thus, the key words in common are summarized as systematic, analysis, evaluation.

CDA researchers define it from their own aspects. Fairclough (1992, p. 9) believes that "criticism aims to discover the relation and reasons behind language." Wodak (1999) indicates that criticism is an explanation of complexity. Actually, criticism in CDA mainly means the revelation of the ideological meaning of the text and the exploration of the relationship between textual function and social reality or social reform. Maingueneau (2006) also distinguishes two orientations of criticism in discourse analysis and considers a 'weak' way as the simple description of structures of texts and talks and a 'strong' way as the practice of fully assuming the purpose of discourse analysis, trying to systematically connect text or conversation structures with social practices and places. Based on Maingueneau's study, we claim criticism in rhetorical criticism as a weak one.

\subsection{Theoretical Support: $C D A, C M A$ and $C L L$}

Due to the similar concepts of criticism in CDA and rhetorical criticism, and the close relationship between metaphor and metonymy, CDA and critical metaphor analysis (CMA) (Charteris-Black 2004) can provide some support for the analysis of metonymy from the perspective of rhetorical criticism. On the one hand, CDA attempts to explain language from cognitive angle with the development of cognitive linguistics (van Dijk 1998). Therefore, the application of cognition-oriented conceptual metonymy into discourse analysis should be related with CDA. Hart (2011) also analyses the functions of conceptual metonymy in CDA. On the other hand, CMA can serve as another support. Charteris-Black (2004) holds that this analytical tool aims to disclose the text builder's intention and that metaphor's function of rhetorical persuasion is based on the mutual conceptual system of the writer and reader. Lakoff (2002) argues that conceptual metaphor plays an important role in the revelation of ideology behind the belief system. Hence, CMA is closely related with ideological analysis.

Besides, compared with metaphor, metonymy is another widely-used rhetorical device to 
enhance the charm of language and achieve some rhetorical effect. The relationship between metaphor and metonymy is complicated. Aristotle regards metonymy as a kind of metaphor, Niemeier (2000) considers metonymy as the basis of metaphor, Dirven (1993) also argues that metaphor and metonymy forms a continuum. Therefore, we are to analyze metonymy from the aspect of rhetorical criticism with the aid of CDA and CMA.

\section{The Criticism of Metonymy in Chinese Media Texts}

We choose Chinese media texts as an analytical object, because metonymy is also ubiquitous in Chinese, either in speech or in writing, in daily communication or in formal occasions. To analyze metonymy, scholars have done this from various perspectives, one of which is CDA. Li (2011) makes an attempt to analyze metonymy from CDA. To be frank, his perspective does not contradict the aspect of rhetorical criticism. CDA provides us with the procedures of description, interpretation and explanation; and rhetorical criticism, as an important part of western rhetoric, can add more nutrition to metonymic analysis. On the basis of previous research, we are to adopt the analytical procedures of description, explanation and evaluation to analyze metonymy in Chinese, which follows the basic road of linguistic research.

\subsection{Description of Metonymy}

Description is taken as the basis of linguistic research. To describe metonymy in a scientific way, the first critical step is to identify and discriminate it. The second step is to delineate the terministic screen constructed by metonymic selection, for the deep relationship between the concepts of metonymic salience and terministic screen.

\subsubsection{Identification of Metonymy}

Those metonymic relations in “天猫对企鹅 在争夺移动购物地盘 (Tmall and Tencent are struggling for the mobile shopping domain)" can be identified at the first sight by native Chinese people, and why? The first parameter is contiguity. Theoretically speaking, the things connected by contiguity are qualified to be metonymy, such as the contiguity between "tian mao" and "Tmall online shoping mall". Second, ICM is considered to be another factor. Lakoff (1987) holds that ICM is an organized conceptual domain, which serves as an aid to recognize metonymy. Actually the part-whole and part-part relationship in ICM is also built on the basis of contiguity, e.g. "qi'e" is part of the ICM of "Tencent" company. Moreover, context is essential and can interpret the variable factors in identification of metonymy, e.g. in the context of "mobile shopping domain", the metonymic operation in "tian mao" and "qi'e" can be figured out reasonably.

To sum up, there are three important parameters to identify metonymy, namely, contiguity, ICM and context, together with observation and retrospection.

\subsubsection{Terministic Screen}

"Terministic screen" is an important concept of Kenneth Burke's rhetorical theory. Burke gets some inspiration from lens and color filter, and gives all kinds of symbolic system or terministic group a name "terministic screen". The lens mentioned by Burke can not naturally present the picture to the audience, but can selectively attract people's attention to some 
aspects of the picture. It reflects some aspects, meanwhile it deflects other aspects. Any terministic screen is a reflection of some aspect of reality. In a word, the reality constructed by human beings is normally a part of reality, not the whole reality.

The selection of terministic screen symbolizes an objective attitude of understanding the world. Due to the limit of view and the complexity of the world, human beings can not observe every aspect of the world. Therefore, we have to understand the world selectively by the terms selected. Actually, the connotation of terministic screen is closely related with salience of metonymic selection, which highlights some salient parts in cognition to shelter other parts. For instance,

（1）浓眉顶替科比出战全明星, 西部主帅定首发人选

The coach of the West decides that the heavy eyebrow will join All-star as the starting lineup because of Kobe's injury)

据 NBA 报道, 本届全明星赛的东道主球队新奥尔良鹈胡队的核心安东尼戴维斯将递补 入选全明星, 以填补科比因伤退赛留下的空缺。

(It is reported from NBA official site that as the core of the host of NBA All-star--New Orleans Pelican, Antony Davis will join the west to fill the vacancy left by Kobe Bryant.) (http://sports.163.com/14/0208/05/9KHOVQ9V00051CA1.html\#p=9KHOS2JF0AI9005)

The context of NBA and the contiguity between "heavy eyebrow" and "people" help one identify "heavy eyebrow" as a metonymic expression, referring to Antony Davis. It builds a terministic screen of Antony Davis, putting Davis' peculiarity--heavy eyebrow to salience, because it is hard to find a second player in NBA with the similar characteristics. The screen also shelters other features of Davis, such as "member of the Tenth Dream team", "Number one of draft", etc.

\subsection{Explanation of Metonymy}

One target of linguistic research is to explain the rules of language. The explanation of metonymy aims to disclose the rhetorical motive of the text builder with the aid of rhetorical situation on the basis of the description of metonymy. Furthermore, ideology, as a common parameter of rhetorical criticism and CDA, is also involved in metonymic explanation.

\subsubsection{Rhetorical Situation and Explanation of Metonymy}

The word meaning is dynamic in particular context. Therefore, the explanation of meaning of metonymy needs to resort to rhetorical situation, put forward by Bitzer (1968). Bitzer holds that rhetorical situation is comprised of three elements: emergency, audience with constraints, constraints influencing orators and audience. We hold that one can not limit rhetorical situation to several elements, it should be classified in its broad and narrow senses. The former sense refers to a social environment or symbolic system which embraces all kinds of social phenomena; while the latter means the context in which rhetorical acts operate. Those two kinds of situation will play some auxiliary role in the explanation of metonymy. For example, 
（2）美列朝鲜为核国家，五角大楼警告平壤勿射导弹

(U.S. lists DPRK as a nuclear country, the pentagon warns that Pyongyang can not launch missiles.) (http://news.sina.com.cn/o/2009-02-13/104815157761s.shtml)

We can infer that "the pentagon" and "Pyongyang" are all involved in metonymic operation based on the parameters of metonymic identification. The former refers to "U.S. department of defense" while the latter represents "North Korea government". The utterance creates a rhetorical situation in its broad sense that North Korea is intended to provoke nuclear war, which worsens the diplomatic relation between DPRK and U.S. Meanwhile it also constructs a linguistic context that "U.S." and "DPRK" both can provide important clues for explanation and help to dig out the optional relevance of word meanings. On the basis of these two rhetorical situations, we argue that the text builder's motive of the selection of the two metonymic expressions lies in highlighting the tense relation between DPRK and U.S., because the pentagon, the location of U.S. Department of Defense, is an authoritative symbol to awe the enemy, and Pyongyang, the capital of North Korea government, symbolizes some political power.

\subsubsection{Rhetorical Motive and Explanation of Metonymy}

In A Grammar of Motives, Burke (1969, p. 43) holds that rhetoric means "the use of words by human agents to form attitudes or to induce actions in other human agents." He also holds that all forms of discourse convey rhetorical motive. By "pentad", Burke argues that the discursive act involves social motive, namely, a rhetorical act conducted by the speaker/writer to the listener/reader. Therefore, Burke's grammar of motive can help to disclose the motive behind language. Actually, in the rhetorical process, discursive organization, including the selection, composition, and extension of the discourse, the choice of information, and the arrangement of discursive structure, is operated around rhetorical motive. Accordingly, the rhetorical function of metonymy is to persuade the audience to accept some attitude, because it can motivate a conceptual system between the speaker/writer and listener/reader. For example, advertisers can motivate people's consumption desire by use of metonymy, which represents clear rhetorical motive.

(3) There is an advertisement in the program "welcome to Shandong province, China" of China's CCTV 1:

$\begin{array}{lll}\text { 中华泰山 } & \text { 天下泰安 } & \text { 绿色钢城 莱芜 } \\ \text { 沂蒙好光 } & \text { 临沂 } & \text { 暗河漂流 地下大峡谷 } \\ \text { 商业古城 } & \text { 山东周村 } & \text { 江北水城 运河聊城 } \\ \text { 奥帆之都 } & \text { 多彩青岛 } & \text { 葡萄酒城 魅力烟台 }\end{array}$

(Mount Tai--symbol of Tai'an city Green steel city--Laiwu city

Picturesque scenery of Yimeng mountain and underground canyon--emblem of Linyi city

Old business site--Zhoucun county Watertown--Liaocheng city

Olympic sailing center--Qingdao Wine city--Yantai)

In this advertisement, metonymic operation is implicitly involved. The advertiser chooses the 
most salient scene to represent the related city, for example, Changyu wine in Yantai. A critical study of metonymy can reveal the advertiser's rhetorical motive. On macro level, the advertiser presents the most attractive city scenery of Shandong province to the audience; on the micro level, the advertiser lists the most salient part of each related city to influence the audience's judgment and attract them to pay a visit. In a word, the text builder aims to achieve identification with the audience and to impel them to take some corresponding action.

\subsubsection{Ideology and Explanation of Metonymy}

Zhang \& Zhang (2012) points out the feasibility of analyzing ideological expressions from the perspective of conceptual metonymy. The criticism of metonymy can not only discover the text builder's rhetorical motive but can excavate the ideological meaning of the text.

Generally speaking, ideology is a term in CDA. In CDA, Fowler (1979, p. 180) points out that "ideology is a system of belief, value, opinion, attitude and category that people rely on to understand the world." Fairclough (1995, p. 44) also holds that "ideology is related with interest and refers to a statement about the world from a specific interest." However, rhetorical critic Crowley \& Stancliff (2011, p. 74) also holds that "an ideology is a set of beliefs, doctrines, and familiar ways of thinking that are characteristic of a group or a culture." Based on the previous research, ideology is a neutral concept, which is a basic concern of metonymy criticism.

Ideology penetrates into every corner of language. Metonymy is no exception. Different metonymies represent different interests and opinions, and stand for different ideological senses. For example,

（4）在中国政府采取干预行动以遏止股市滑坡的三周后, 股价再次下挫, 上证综指出现 八年来最大单日跌幅。现在北京面临一个不值得羡慕的选择: 加码救市, 或是摘掉无所 不能的面具。向市场力量交出控制权不仅让共产党难以忍受，也与中国政治生活至今盛 行的家长作风格格不入。

(Three weeks after China intervened to stem a stock market slide, share prices have tumbled again, with the Shanghai Composite recording its worst day in eight years. Beijing now faces an unenviable choice: to sink even more into propping up the market, or let slip its mask of invulnerability. Ceding control to market forces not only sticks in the communist craw, but goes against the paternalism that still echoes through Chinese political life. (http://www.ftchinese.com/story/001063217)

In (4), “共产党 (the Communist)” metonymically stands for “Chinese government” and meanwhile constructs a terministic screen, which puts "the ruling party role of the Party" into prominence. In this linguistic context, this metonymic operation represents an ideological meaning to some extent. Moreover, based on the broad rhetorical situation, which refers to the fact that western countries always criticize China government's attempt to control the stock market, we can thus make the inference that the author purposefully views "China government" as “共产党 (the Communist)" with an ideological sense in the mind. what's more, the author aims to provoke British's negative feeling towards China and to influence 
China's image on international stage by using this metonymy.

The description of metonymy paves the way for its explanation, which will sequentially lay the foundation for its evaluation. Whether the metonymic selection is good or not needs to be evaluated by relevant standards.

\subsection{Evaluation of Metonymy}

The evaluation procedure needs to be reinforced, compared with the description and explanation part which is the major concern of previous research. The evaluation of metonymy, by its name, means evaluating the conclusion of description and explanation based on relevant standards, in order to disclose the ultimate target of metonymy criticism. Evaluation is a subjective process and varies from evaluator to evaluator, therefore, the standards tends to be particularly important.

\subsubsection{Standards of Evaluation}

Foss (2004, pp. 21-22) holds that "justification, reasonable inference and coherence are those three standards for rhetorical criticism." These standards are set on the macro-level. Campbell \& Burkholder (1997) mentions artistic, truth, effect and ethical standards, which are suitable for metonymic evaluation in this study. Firstly, metonymy is a rhetorical device, and also a cognitive tool to see the world. It is always used in speech or writing to enhance the charm of language and thus to achieve ideal rhetorical effects, therefore, artistic standard can be chosen to evaluate it. Take “桃花盛开 (the blossoming peach flower)" as an example, many Chinese choose this name as their nickname of Tencent QQ (a popular chat software in China developed by Tencent company), which involves a metonymic processing, namely, “桃花盛 开” stands for the people. Anyway, “桃花盛开” creates a beautiful picture for readers, which matches the artistic standard. Secondly, the description of metonymy indicates the terministic screen created by the salience feature of metonymy. Due to the terministic screen's ability to reflect and deflect reality, truth standard can be viewed as another standard, namely, judging to what extent can the terministic screen reflect the reality. Moreover, effect standard can be seen as the third one, because one can evaluate the metonymic selection directly by its effect in the audience. However, it is hard to measure the effect. Just as Campbell \& Burkholder (1997) mentions, it is always not clear to see the effect of text, whether in a short or long period. Furthermore, ethical standard, which means to measure whether the value held by the rhetor follows the main current of human society, is too broad to grasp, therefore, we don't list it among the standards of metonymy criticism. Eventually, owing to the fact that metonymy always exists in a text, we take textuality as the fourth standard. Beaugrande \& Dressler (1981) put forward the seven standards of textuality: cohesion, coherence, intentionality, acceptability, informativity, situationality and intertextuality. For the standards of metonymy criticism, we hold that cohesion and coherence can serve to observe metonymy's role in building cohesion and coherence for the text, intentionality can investigate metonymy builder's rhetorical motive in the selection of metonymy, acceptability overlaps the effect standard, informativity is determined by intentionality, situationality can disclose the relation between metonymy and situation, and intertextuality aims to analyze metonymy builder's knowledge of other texts. Therefore, to avoid overlapping, textuality can 


\section{Macrothink \\ Education and Linguistics Research \\ ISSN 2377-1356 \\ 2015, Vol. 1, No. 2}

be capsuled into cohesion, coherence, intentionality and situationality.

To sum up, metonymy can be evaluated by artistic, truth, effect and textuality standards.

\subsubsection{Target of the Evaluation of Metonymy: Identification}

Identification is the core concept of Burke's new rhetoric system, while persuasion is the center of classic rhetoric. The former is the aim of the latter. Deng $(2011$, p. 41) holds that "identification is concept of hierarchy and continuity." Burke divides identification into sympathetic identification (identification in thoughts and viewpoints), opposition identification (identification due to the same opponent) and unconscious identification (rhetors employ particular words to get identification from the audience subconsciously).

The target of metonymic evaluation lies in the investigation of metonymy builder's intention to achieve identification by persuading the audience. What's more, the target embraces the production of metonymy, namely, the audience can create appropriate metonymic expressions in certain linguistic context. To be frank, the two targets can not be directly perceived. On the one hand, the identification between the text builder and audience can not emerge instantly. For instance, Sohu sports (a famous China online sports website) issued a video with the title “高峰北京完婚, 央视名嘴到场祝贺 (One CCTV popular talk-show host shows up in Soccer star Gaofeng's wedding part in Beijing)" on Oct. 7th, 2011 (http://s.sohu.com/20111007/n321411443.shtml). In the title, we can infer that “央视名嘴 (CCTV popular talk-show host)" is a metonymic expression, in which “名嘴 (literally means famous mouth)" stands for "celebrity" with the operation of part-for-whole relation. According to the statistics by Aril. 22nd, 2014, this video has been played for 5,876,160 times. We can see from the effect that the metonymic expression “央视名嘴” does play some auxiliary role in the identification between the text builder and audience because it can attract the audience to play it for the weird link between soccer star and CCTV talk-show host. On the other hand, it is still hard to measure the effect in terms of the production of metonymy, just because the production of metonymy in appropriate situations needs a systematic training in language teaching, which is another theory of metonymic competence.

\section{Rhetorical Criticism of Metonymy Model}

We can put what we discussed above into a diagram in order to clarify the procedure of metonymy criticism. 


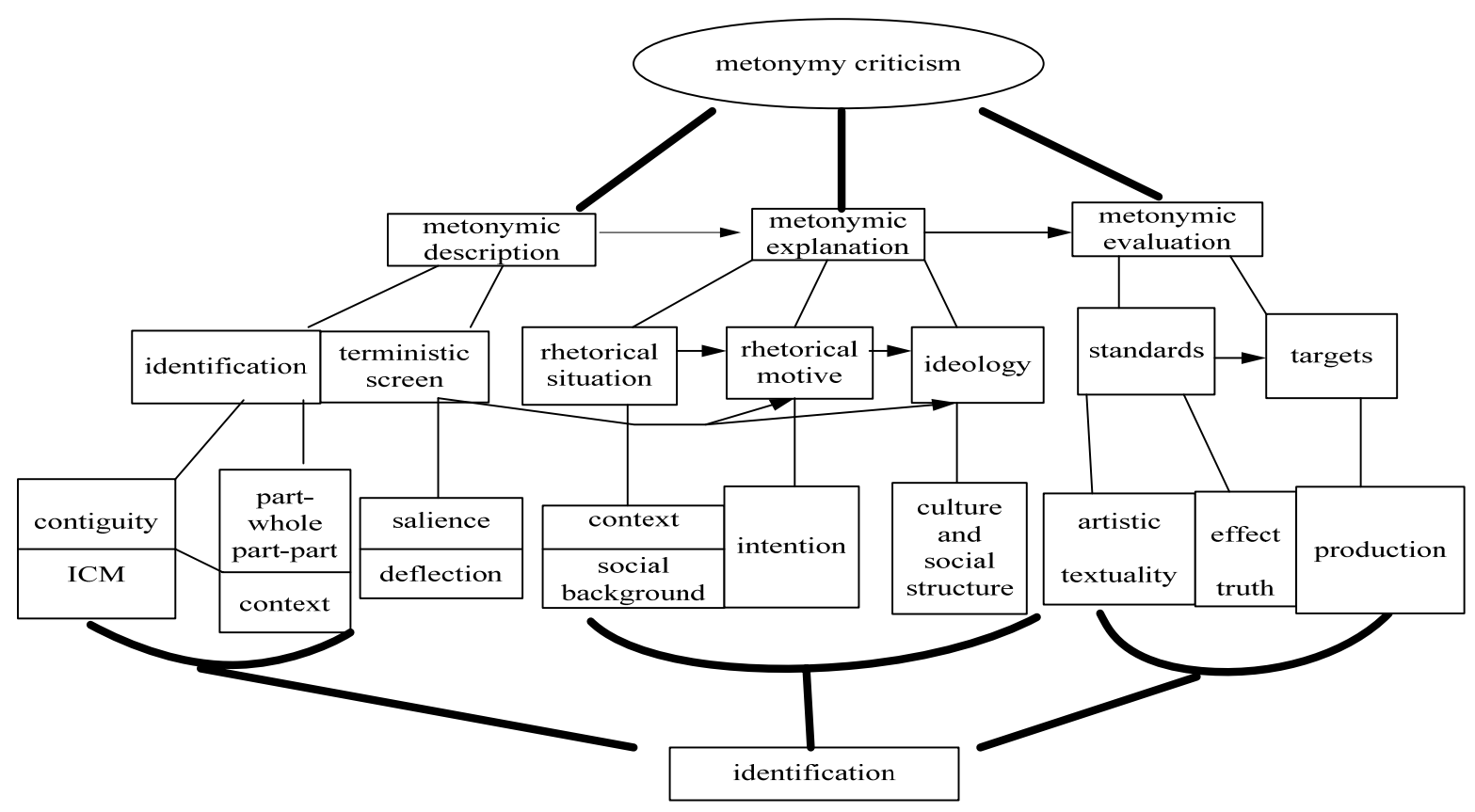

Figure1. Rhetorical criticism of metonymy model

\section{Case Study}

We will test the feasibility and operability of metonymy criticism by the following example.

(5) 深圳“"8 毛钱治愈 10 万元病”事件患儿前天从同济医院小儿科出院, 患儿父亲陈刚亲 手将一封致歉信交给同济医院宣传部的负责人手里, 称自己的无知及一时冲动使深圳儿 童医院受社会舆论的冲击, 在此道兼。这场 8 毛门尘埃落定。

(The baby who was rumored to be cured with 12 cents rather than 1,600 USD left the pediatrics of Tongji Hospital, and his father handed in an apology letter to the cadre of department of publicity of Tongji Hospital, saying it is his ignorance that pushes Shenzhen Children Hospital into the storm of public opinion. Up to now, the social event comes to an end.) (http://news.ifeng.com/opinion/gundong/detail_2011_10/30/10265048_0.shtml)

Description of Metonymy

Based on the parameter of metonymic identification, "8 毛门 (15 cents gate)" involves metonymic operation, that is, "8 毛" is a sub-model of the ICM created by "8 毛门". Therefore, "8 毛门" refers to the rumor that the baby can be cured with 12 cents rather than 1,600 USD. “门 (gate)” indicates a negative sense, and “8 毛门” constructs a kind of terministic screen, emphasizing " 8 毛" and sheltering other parts of the event, such as the baby, the tense relation between doctors and patients in China, etc. 
Explanation of Metonymy

According to the linguistic context ("the baby can be cured with 12 cents instead of 1,600 USD" provides clues for "8 毛门”) and the social context (A baby in Shenzhen Children Hospital who was diagnosed as congenital giant colon on September 2011, was told that the cost to cure it was 1,600 USD. However, he was transferred to Guangzhou Children Hospital and was informed that he could be cured with 12 cents. After this issue was exposed to the media, the hospital and the patient stuck to their own arguments), the selection of "8 毛门" puts the issue to focus and demonstrates the author's intention to highlight the increasingly tense relation between doctors and patients. Moreover, "8 毛门" also reflects some deep social problems and thus discloses the ideological meaning. The majority of Chinese media reprint the issue with such titles as “8 毛门(12 cents baby)", “8 毛治好 10 万元病(12-cents treatment for 1600 USD)", which loads the two parties with great pressure. Therefore, we need to measure the responsibility of the media to report the news event in an objective and justified environment.

\section{Evaluation of Metonymy}

Firstly, the metonymic selection provokes readers' curiosity about the event and creates appropriate rhetorical effect, therefore, it meets the artistic standard; secondly, "8 毛门" relatively depicts the situation of treatment at that moment in Guangzhou Children Hospital, which corresponds to truth standard; Thirdly, for the effect, this expression succeeds in achieving the identification between the writer and the audience, because " 8 毛门" was listed among Chinese top ten health news in 2011; Fourthly, “8 毛治好 10 万元病(12-cents treatment for 1600 USD)" and "8 毛门(12 cents gate)" forms an anaphora and thus build the textual cohesion, which matches the textuality standard.

\section{Conclusion}

The research on metonymy is galloping in the past two decades, such as Littlemore (2015) who was once an expert on metaphor now turns to metonymy studies, however, most scholars put more ink on the description and explanation but less on the evaluation and production. In this paper, we attempt to systematically describe, explain and evaluate metonymy in Chinese media texts from the perspective of rhetorical criticism, in order to disclose the rhetorical motive and ideology behind the expression with metonymic operation. However, the study does not make the classification of metonymy in different Chinese media texts, such as political news, economic news, etc, which needs to be studied in the future.

\section{Acknowledgements}

The research is financed by Chinese Scholarship Council and Social Science Research Project of Shandong Province, P.R. China. No. 13DWXJ10.

\section{References}

Althouse, M. et al. (Eds.). (2009). Rhetorical Criticism: Perspectives in Action. Lanham: Lexington Books. 
Andrews, J. R. (1983). The Practice of Rhetorical Criticism. New York: Macmillan Publishing Co., Inc..

Beaugrande, R. de., \& Dressler, W. U. (1981). Introduction to Text Linguistics. London: Longman.

Bitzer, L. (1968). The rhetorical situation. Philosophy and Rhetoric, 1, 1-14.

Black, C. J. (2004). Corpus Approaches to Critical Metaphor Analysis. NY: Palgrave Macmillan. http://dx.doi.org/10.1057/9780230000612

Black, E. (1978). Rhetorical Criticism: A Study in Method. Madison: University of Wisconsin Press.

Burgchardt, C. R. (Ed.). (2010). Readings In Rhetorical Criticism (4th Edition). Strata Publishing, Inc.

Burke, K. A. (1969). A Grammar of Motives. California: University of California Press.

Campbell, K. K., \& Burkholder, T. R. (1997). Critiques of Contemporary Rhetoric. Belmont: Wadsworth.

Crowley, S., \& Stancliff, M. (2011). Critical Situations: A Rhetoric for Writing in Communities with Additional Material. Boston: Pearson Education Company. http://dx.doi.org/10.1111/j.1467-8705.2011.01988.x

Deng, Z. Y. (2011). Rhetorical Theory and Rhetorical Philosophy: A Study on Kenneth Burke. Shanghai: Xuelin Press.

Dirven, R. (1993). Metonymy and metaphor: Different mental strategies of conceptualization. Leuvense Bijdragen, 2, 1-25.

Fairclough, N. (1992). Discourse and Social Change. Polity Press.

Fairclough, N. (1995). Critical Discourse Analysis: The Critical Study of Language. London: Longman.

Foss, S. K. (Ed.). (2004). Rhetorical Criticism: Exploration and Practice. Long Grove: Waveland Press.

Fowler, R., Hodge, G., \& Trew, T. (1979). Language and Control. London: Routledge and Kegan Paul. http://dx.doi.org/10.1080/00207177908922810

Hart, C. (2011). Moving beyond metaphor in the cognitive linguistic approach to CDA: Construal operations in immigration discourse. In C. Hart (Ed.). Critical Discourse Studies in Context and Cognition (pp. 71-92). Amsterdam: John Benjamins. http://dx.doi.org/10.1075/dapsac.43.09har

Hart, R. P., \& Daughton, S. M. (2005). Modern Rhetorical Criticism. Boston: Pearson/Allyn and Bacon.

Kuypers, J. A., \& King, A. (2005). What is rhetoric? InJ. A. Kuypers (Ed.), The Art of 


\section{Macrothink \\ Education and Linguistics Research \\ ISSN 2377-1356 \\ 2015, Vol. 1, No. 2}

Rhetorical Criticism (pp. 1-12). Boston: Pearson Education.

Lakoff, G., \& Johnson, M. (1980). Metaphors We Live By. Chicago: The University of Chicago Press.

Lakoff, G. (1987). Women, Fire and Dangerous Things: What Categories Reveal about the Mind. Chicago: The University of Chicago Press. http://dx.doi.org/10.7208/chicago/9780226471013.001.0001

Lakoff, G. (2002). Moral Politics. Chicago: University of Chicago Press. http://dx.doi.org/10.7208/chicago/9780226471006.001.0001

Li, K., \& Li, S. K. (2011). A study of metonymy from the perspective of embodied philosophy. Journal of Tianjin Foreign Studies University, 2, 24-29.

Li, K. (2011). Towards the mode of critical metonymy analysis. Contemporary Rhetoric, 4, 78-84.

Littlemore, J. (2015). Metonymy: Hidden Shortcuts in Language, Thought and Communication. Cambridge: CUP. http://dx.doi.org/10.1017/cbo9781107338814

Maingueneau, D. (2006). Is discourse analysis critical? Critical Discourse Studies, 2, 229-235. http://dx.doi.org/10.1080/17405900600908145

Niemeier, S. (2000). Straight from the heart metonymic and metaphorical explorations. In A. Barcelona (Ed.), Metaphor and Metonymy at the Crossroads (pp. 195-214). Berlin/New York: Mouton de Gruyter.

Ott, B., \& Dickinson, G. (Eds.). (2012). The Routledge Reader in Rhetorical Criticism. Routledge.

Stefanowitsch, A. (2006). Corpus-based approaches to metaphor and metonymy. In A. Stefanowitsch, \& G. Th. Stephan (Eds.). Corpus-based Approaches to Metaphor and Metonymy (pp. 1-16). Berlin/New York: Mouton de Gruyter. http://dx.doi.org/10.1515/9783110199895

van Dijk, T. A. (1998). Ideology: A Multidisciplinary Approach. London: Sage.

Wang, X. H. (2011). A cognitive pragmatic study of metonymic expressions: An integrated model of relevance theory and cognitive linguistics. Modern Foreign Languages, 1, 34-41.

Wodak, R. (1999). Critical discourse analysis at the end of the $20^{\text {th }}$ century. Research on Language and Social Interaction, $1 \quad \& \quad 2, \quad 185-193$. http://dx.doi.org/10.1080/08351813.1999.9683622

Zhang, H., \& Zhang, T. W. (2012). Cognitive metonymy approach to critical discourse analysis. Foreign Language and Literature, 3, 41-46. 


\section{Macrothink

\section{Copyright Disclaimer}

Copyright reserved by $\mathrm{Ke} \mathrm{Li}$ and Shukang $\mathrm{Li}$, with first publication rights granted to the journal.

This article is an open-access article distributed under the terms and conditions of the Creative Commons Attribution license (http://creativecommons.org/licenses/by/3.0/). 